Article

\title{
From Victim to Hangman? Ennahda, Salafism and the Tunisian Transition
}

\author{
Francesco Cavatorta ${ }^{1, *,+}$ iD and Stefano Torelli ${ }^{2,+}$ \\ 1 Department of Political Science, Laval University, Quebec, QC G1V 0A6, Canada \\ 2 Italian Institute for International Political Studies (ISPI), 20121 Milan, Italy; stefanom.torelli@gmail.com \\ * Correspondence: francesco.cavatorta@pol.ulaval.ca \\ + We are very grateful to the three referees whose insightful comments have improved the manuscript \\ considerably. All errors remain of course our own.
}

\begin{abstract}
The article revisits the notion of post-Islamism that Roy and Bayat put forth to investigate its usefulness in analysing the Tunisian party Ennahda and its role in the Tunisian transition. The article argues that the notion of post-Islamism does not fully capture the ideological and political evolution of Islamist parties, which, despite having abandoned their revolutionary ethos, still compete in the political arena through religious categories that subsume politics to Islam. It is only by taking seriously these religious categories that one can understand how Ennahda dealt with the challenge coming from Salafis.
\end{abstract}

Keywords: political Islam; Tunisia; Salafism; Ennahda democratization

check for updates

Citation: Cavatorta, Francesco, and Stefano Torelli. 2021. From Victim to Hangman? Ennahda, Salafism and the Tunisian Transition. Religions 12: 76. https://doi.org/10.3390/rel12020076

Academic Editor: Mojtaba Mahdavi Received: 20 October 2020

Accepted: 20 January 2021

Published: 24 January 2021

Publisher's Note: MDPI stays neutral with regard to jurisdictional claims in published maps and institutional affiliations.

Copyright: (c) 2021 by the authors. Licensee MDPI, Basel, Switzerland. This article is an open access article distributed under the terms and conditions of the Creative Commons Attribution (CC BY) license (https:// creativecommons.org/licenses/by/ $4.0 /)$.

\section{Introduction}

Political Islam has been a prominent research topic for the last three decades and the literature on it is as impressive as it is broad. While it is impossible to do full justice to how scholars have approached the topic, there are three clusters of research that can be identified. First is the ever-present debate about the compatibility between Islam and democracy, which informs the way Islamist parties are analysed (Schwedler 2011). Whether one is inclined to accept or reject the argument of the incompatibility between Islam and democracy, what emerges is that the beliefs and activities of Islamist parties have been studied as "evidence" of the validity-or lack thereof-of the incompatibility argument. Closely connected to this cluster is the one about the ideological developments that Islamist parties have gone through over time, suggesting that they have accepted democratic procedures, individual liberal rights (El-Ghobashy 2005) and, crucially, the idea of a civil state (Gerges 2013). Thus, they are no longer about "conquering" power to install an Islamic state-however ill-defined its institutions and governing mechanisms might be. They have instead moderated to such a degree that they want to contribute to the construction of a democratic civil state. Moving away from studies examining ideological developments, a third cluster of research has focused extensively on the organizational and operational aspects of Islamist parties, looking at their participation in elections and their efforts at cross-ideological coalition-building (Clark 2010). Although these research clusters can be seen as analytically separate, they are also intertwined because they examine a fundamental "change" that the vast majority of scholars noted, namely ideological moderation. Only supposedly marginal Islamist actors-Salafis-appear to have preserved a genuinely revolutionary ethos (Bunzel 2015). The notion of post-Islamism has been employed since the mid-1990s to capture this change. The thesis of post-Islamism, which finds its roots in the works of Asef Bayat (1996, 2007, 2010) and Olivier Roy (1992), was put forth as an answer to the changes in Islamist politics and activism that began occurring in the 1990s. Asef Bayat and Olivier Roy conceptualised post-Islamism differently and drew inspiration from different geographical contexts, but agreed on the idea that political 
Islam had lost its original revolutionary drive and had abandoned, in the case of the majority of Islamist parties and movements, the belief in subsuming politics to Islam. From a concrete perspective, this meant giving up on transforming both politics and society through religion-inspired reforms. Although Bayat and Roy did not deny Islamism's authoritarian tendencies and problematic political role, their argument was that from the early 1990s onward there was nothing genuinely radical in the ideological developments, policy solutions and governance mechanisms mainstream Islamist movements proposed. Roy argued that the Islamist ideological project had failed because it had been unable to come to power-whether through violence or the ballot box-and revolutionize social, political and economic relations through the creation of a theocratic Islamic state. The move to espouse democratic procedures and limited individual rights was therefore an ideological admission of defeat and failure on the part of Islamists. For Roy, the notion of post-Islamism captured this failure. For his part, Bayat (1996, p. 43) argued that "Oliver Roy's contention about the "failure of political Islam" did not mean the end of Islamist activism and discourse" and employed the notion of post-Islamism to describe the way in which Islamist politics would progressively espouse a vision of society where religious categories would fuse with democracy and liberal rights. In doing so, "Islamists would create a de facto secular space by re-routing religious activism away from the state and, sometimes, from political issues altogether" (Lauzière 2005, p. 241).

The 2011 Arab uprisings re-energised the literature on Islamism and a raft of new studies reinvigorated the three research clusters following the rise of Islamist parties and movements across the region (Al-Anani 2012; Schwedler 2013; Buehler 2018). Their electoral success on the political scene demanded that scholars engage again with the concept of post-Islamism to account for post-revolutionary developments. This article begins with a discussion on how the concept of post-Islamism has been employed and, following Cavatorta and Merone (2015), examines the two strands that Asef Bayat and Olivier Roy represent. The article then analyses how useful post-Islamism is when applied to the Tunisian Ennahda party in light of the transformations that have affected it in the context of the successful Tunisian transition to democracy. The final and most substantive section is then dedicated to the way in which one can look at how the notion of postIslamism works in practice and how it can be employed to understand intra-Islamist competition. Although the literature has engaged with both the notion of post-Islamism and the Ennahda party, the article contributes to a clearer understanding of how the ideas of change and adaptation that are inherent in Bayat's conceptualization of post-Islamism can be understood in practice. The rivalry between Ennahda and the Tunisian Salafi movement during the transition to democracy highlights the relevance of religious categories and the central place Islam still occupies when it comes to justify the very nature of participation in institutional politics.

\section{Post-Islamism: A Theoretical Discussion}

The notion of post-Islamism that Roy first and Bayat later put forth had considerable implications for the way in which Islamist parties and movements have been examined. The two scholars employed the notion to look at slightly different phenomena drawing from two different case-studies, but their arguments share sufficient similarities to warrant a common discussion. In the mid-1990s Roy and other colleagues from the French school (Lauzière 2005) argued that the political project of Islamists to take over states and set-up a political system within which religion would prevail over politics had failed quite spectacularly. Whether though violence, the ballot box or social activism Islamists had proved unable to secure power, leading to a profound rethink of both ideological tenets and methods of political engagement. In a 2014 Browers (2014) summarized Roy's argument succinctly: "Islamism had failed, both intellectually and politically." In this respect, post-Islamism represents the retreat of Islamist politics away from the quest for state power and the implementation of sharia-the key Islamist demand for decades-and towards the articulation of Islamist politics and positions in private expressions of religiosity. For Roy, 
the ideological changes Islamist parties were beginning to go through represented the failure of their revolutionary project and the inability to ensure the dominance of religion over politics. Thus, for a time, this failure led to a "retreat" from institutional politics in favour of other forms and arenas of engagement, such as for instance through economic success in a market economy (Haenni 2005) or in dawa activities (Lauzière 2005). Thus, the notion of post-Islamism also captured a sort of personalised and non-traditional mobilization through pious behaviour in "silent" opposition against regimes, like the Tunisian one, intent on repressing political expressions of Islamism (Bayat 2010; Haugbølle and Cavatorta 2012). This meant that politically organized mobilization through the categories of religion was now a much more personal affair. It is through this idea of retreat of politicized behaviour into the private sphere that Roy's post-Islamism connects with Bayat's. Focusing on the case of Iran rather than on the Arab world, Bayat's conceptualisation of post-Islamism does not see Islamism as a failure because the Islamic Republic was and still is a stable system of government and interlocking institutions where religion is both central and crucial. However, Bayat also suggests that by the mid-1990s the "mythical revolutionary phase" of Islamism was over and the election to the presidency of the reformist Khatami in 1997 was a clear indication of the loss of Iranian Islamism's revolutionary drive. For Bayat (2010), post-Islamism "is an attempt to turn the underlying principles of Islamism on its head by emphasising rights instead of duties, plurality in place of a singular authoritative voice, historicity rather than fixed scriptures, and the future instead of the past." As he had already explained in the mid-1990s, Islamic activism would not disappear from the region because religion was still the primary mobilizing category, but such activism had mutated into the quest for the merging of Islam with notions of liberalism and democracy. Following on from this, Bayat discussed the idea of adaptation of Islamist activism to the requirements of secular modernity and politics. In short, a vision of society that would go beyond the unique role of Islam towards post-Islamic political and social organizing principles of governing that would encompass religion and liberal politics instead.

Following the Arab uprisings and the electoral success of Islamist parties, Roy contended that this did not reflect the return of the original Islamist political revolutionary project. Quite the contrary, Roy $(2012$, p. 7) argued that following the fall of authoritarian regimes "Islamist parties may have more power and freedom to maneuver, but they too will find themselves being pushed to adjust to the democratization process." In having to accept the environmental pressures surrounding them, they inevitably become mainstream political actors, who, according to Roy, have to accept the primacy of politics over religion and the inevitably subscribe to and abide by the procedures of democracy and the value of individual freedoms. In short, despite their electoral success, Political Islam as an ideological revolutionary was still a failure. For Bayat (2013), post-Islamism after the uprisings did not necessarily equate with the end of Islamism or with its failure. In fact, it seemed to validate the process of fusion between religion and liberal-democratic politics, which would underpin a post-Islamist society. This is because Islamists had for some time had stopped imagining Islam "as a complete and ready to use 'divine system, with its superior political model, cultural codes, legal structure and economic arrangements-a system that responds to all human problems" (Bayat 2007, as cited in Yilmaz 2011). Rather, as Al-Anani (2014, p. 347) aptly puts it in a review of Bayat's 2013 book (Bayat 2013), post-Islamism revealed itself as "an ongoing process of change, adaptation and manifestation."

The rise of Islamist parties and movements following the Arab uprisings (Hamid 2011) invalidates to an extent the notion of post-Islamism Roy put forth. Roy is correct when he emphasizes the move away from the original revolutionary project Islamists espoused with the centrality of sharia and the creation of the Islamic state once in power. However, the way in which Islamists engaged in the political arena and employed religious categories to justify their policy preferences as well as undermine their ideological adversaries should provide pause. Roy specifically argued that there was no point in re-engaging with discussions about the supposed double-agenda of Islamist parties because they had committed to democratic principles and renounced revolutionary goals, but it was difficult for many to reconcile 
this with the electoral victories of Islamist parties and the fears that they generated in large sectors of domestic society. While some Islamist parties such as the Egyptian and Libyan Brothers were more orthodox in their thinking and policy preferences than their more accommodating Tunisian and Moroccan counterparts, religious categories were central in their vision of a new post-uprising society. In short, what contradicted Roy's point about the failure of political Islam was that Islamist parties did not "hide" their traditional thinking about the relationship between politics and religion and that the Arab public clearly supported Islamism and its project for governing society. While it is true that Islamist electoral victories might have been brought about because of the perception that they would manage the economy much better (Masoud 2014), there is little doubt that issues related to identity, women's rights and the place of religion in the public sphere had a considerable echo (Wegner and Cavatorta 2019). Some studies suggest that while ordinary citizens are favourable to democracy, they are also quite favourable to the implementation of religious law, especially when it comes to individual rights (Teti et al. 2019). Islamist parties did not always campaign on religious issues, but such issues became central to the political debate, suggesting that Islamism's original project of revolutionising the social sphere had not completely disappeared.

The electoral victories of Islamist parties and the centrality of religious precepts in the public sphere confirms that, far from being politically exhausted, the appeal of Islamism is still powerful, and that political power was still the goal. In this respect it appeared that only repression and strong constraints in electoral rules had prevented Islamist parties from taking power during the 2000s (Willis 2004; Brown 2012; Kraetzschmar and Cavatorta 2010), putting to rest the notion that the Middle East and North Africa were operating in a post-Islamist environment as Roy defined it. The fall of authoritarian regimes removed those constraints and Islamists were once more the protagonists of political life.

However, the electoral success of Islamist parties and their desire to control the machinery of the state did not have revolutionary undertones, as Islamists generally strived to be conciliatory, although this was more the case for some parties than others. This fact supports Roy's contention that it is impossible for Islamist parties to propose a political agenda that is based on the beliefs and policies of the early days of Islamism, indicating that the revolutionary drive is truly over. The main problem with Roy's argument though is the inability to conceive of Islamism as other than an exhausted political project because the mix of religion and politics has not disappeared, but it has been remodelled. A more complex vision of the development of Islamism should see it as a phenomenon that is constantly evolving in a "conversation" with social and economic changes taking place in society, which it attempts to influence and is also influenced by in a sort of feedback loop. In a sense, Islamist parties and movements do not cease to be "Islamist" because they might no longer be as revolutionary as they were or because their view of the state and how to govern a society has changed or adapted to new circumstances, insofar as their participation in the system, their positions vis-à-vis adversaries and allies as well as the machinery of the state are still dependent on the religious categories that are mobilized. Thus, the references to religious symbolism and language are still employed to convey a message of differentiation from other political actors and the new policy positions are the outcome of a process of internal revision that is ideologically justified through religious categories and thinking. The desire to acquire power in order to change society might not be synonymous with an authoritarian revolutionary project in disguise, but Islam remains central in thinking about politics and operating in the political system to radically change Arab societies. To summarize, there are three problems with Roy's failure of political Islam. First, there is a rigidity to the concept of post-Islamism which sits uneasily with the ideological justifications and policy preferences of post-Spring Islamists. Second, the notion of failure seems to imply that the original revolutionary project-Islam is the solutioncannot be revised and this is demonstrably not the case as the rise of Salafism suggests. Whether through violence, activism or the ballot box Salafis have revived the centrality of sharia and the Islamic state, convincingly placing religion well above politics. Third, the 
transitions in Egypt and Libya failed because of the ideological intransigence of Islamists and their secular counterparts. This suggests that in daily "politicking" the question of the relationship between religion and politics is still relevant.

Bayat's notion of post-Islamism as constant change and adaptation of both discourse and practice has been presented as more useful because it implies that Islam is still crucial to the way in which Islamists conduct politics. The post-uprisings political reality saw Islamists become the protagonists of political life, proving they were better organized and moving quickly and efficiently to take up institutional roles. This is an important development compared to what Bayat was discussing in the mid and late 2000s when he emphasized the private role Islam played in non-movements of contention and opposition. The Muslim Brotherhood in Egypt, the Party of Justice and Development in Morocco and Ennahda in Tunisia in particular mobilized members, sympathizers and voters according to the traditional arsenal of political parties: putting in place clear structures across the country, planning the media campaign, selecting candidates, and focusing on publicising a political manifesto containing specific proposals on how to govern. Thus, the idea that Islamist parties had melted away because of their inability to take power in the previous decades and because of the "privatisation" of religious behaviour was dismissed in the face of their growing importance (Cavatorta and Storm 2018). All this points to the greater usefulness of Bayat's understanding of post-Islamism as a progressive fusion of Islam and liberal-democracy because many Islamists argued that they were leading "civil parties with Islamic references" (McCarthy 2018). In this sense their participation and victories in free and fair elections symbolized the success of their adaptation to modern politics and the marginalization of religious imperatives to conduct politics. Although this notion of post-Islamism has been deemed more useful and more correct, it also suffers from two problems. Although Bayat recognized that Islamic activism per se would not end because of the importance of religion in the region, he envisioned it would connect to liberal-democratic principles. This has not necessarily been the case. The failed Egyptian and Libyan transitions, the civil wars in Syria and Yemen all suggest that many different types of Islamists still mobilize according to traditional interpretations of the relationship between religion and politics whereby the first has primacy over the second. Furthermore, even in cases where some Islamist actors could be considered post-Islamist in Bayat's thinking, they still have to employ religion to justify policy decisions vis-à-vis their members (Netterstrøm 2015) and, crucially, compete with revolutionary Islamists (Salafists) through religious categories (Merone 2015).

To conclude, the notion of post-Islamism that Roy worked with has been severely tested in the aftermath of the 2011 Arab uprisings. Although it provides a crucial insight, namely that over time Islamist parties have abandoned many of their core revolutionary demands, splintering in the process the Islamist camp, Political Islam has not failed. Islam remains the central factor in explaining their internal changes, their positioning in the political system and the success of movements which continue to hark back to the "Islam is the solution" slogan. Bayat's understanding of post-Islamism is more flexible because it can be interpreted as a further development of Islamist ideology, which has progressed to an extent that it has almost entirely reformulated its political objectives. If we look beyond the notion of failure and accept that ideological adaptation does not automatically translate into the dismissal of the whole ideological apparatus of Islamism, the notion of post-Islamism can apply to those movements issued from a Muslim Brotherhood tradition participating in and/or wishing to participate in democratic institutions. Bayat's notion though fails to account for the way in which many Islamists movements still employ religion as the "trump card" in their internal debates and in their relations with other political actors in the system despite the acceptance of democratic mechanisms and individual freedoms.

\section{Post-Islamism and Ennahda}

The Tunisian Islamist party has been considered the most prominent example of Bayat's post-Islamism due to the changes and adaption it experienced over time. The 
majority of scholars following the fortunes of the party agree that Ennahda represents the prototype of an Islamist movement that successfully moderated over time, responding to surrounding environmental pressures and social changes. Nothing seems to suggest the failure of the Islamist project more than the official renunciation of the party to Political Islam, which occurred at the 10th party conference held in 2016, and its declining electoral appeal, partly due to the perception of having "sold out" its revolutionary vision. As the party's leader Ghannouchi (2016) explained following the conference, there was no longer the need in Tunisia to protect religion from the interference of the state because the new liberal-democratic constitution permitted citizens to live their spirituality as they pleased. It followed from that there was no longer the need for a party to represent religion per se and therefore Ennahda would be no longer a member of the Islamist family, but it would be squarely in the camp of Muslim Democrats. To signal the break with the past, the party and the movements were officially separated. Although many critics of Ennahda still hold on to the idea that the party has a secret agenda that calls for the Islamization of society, the reality is that both organizationally and ideologically the party had not been promoting the traditional key demands of political Islam for quite some time. For some authors (Allani 2009) the party already moderated well before the Arab uprisings, particularly when one examined in detail the ideological transformation of its leader Rachid Ghannouhci. By the late 1990s in fact, he had abandoned his Islamist radicalism and progressively subscribed to the notion that democratic politics and Islam were inherently linked and mutually reinforcing (Tamimi 2001).

From Roy's perspective, this progressive ideological transformation (Cavatorta and Merone 2013) is in line with the notion of failure of Islamism's revolutionary project. Furthermore, while in power, the party made a number of extremely pragmatic political choices (Netterstrøm 2015). It refrained for instance from pushing for the introduction of references to sharia into the new constitution, which contradicted quite openly what the party had stood for. The acceptance of consensual policy choices distant from its original ideological tenets demonstrate that, since its electoral victory in October 2011, the party contributed positively to the institutional success of the process of democratization (Marks 2018). This does not mean that its presence on the Tunisian political scene was uncontroversial and non-confrontational (Lesch 2014), but, ultimately, it led to the consolidation of democracy, as did its participation in a grand coalition after the 2014 elections.

All of this would suggest that Olivier Roy's point about the political and ideological failure of Islamism is correct in so far as Ennahda ditched over time all the radical elements of its original political project (an Islamic state with sharia at its centre) to become an establishment party in a liberal-democratic Tunisia, explicitly accepting its values and the necessity for pragmatism and flexibility. Moreover, the second post-Islamist aspect-the dilution of political Islam into "non-movements" and the privatization of religiosity-is also on show in Tunisia where the party itself lost 32 seats over three elections (it had 89 seats in 2011, 69 in 2014 and 57 in 2019), suggesting that Islamism is no longer as attractive to voters.

Under closer scrutiny though both implications of Roy's post-Islamism do not appear as solid as one might think and Bayat's conceptualization seems more apt at capturing the reality. First, it would be too simplistic to argue that Ennahda's ideological content is no longer Islamist now that the party has accepted liberal-democracy and labels itself "Muslim democratic" (McCarthy 2015). While it might not have the rigid ideological framework of the past and might be seen as having betrayed its original political project, it should be highlighted that ideologies are not fixed, and that adaptation captures better the process of change the party has gone through. As argued elsewhere, ideologies "constantly interact with the political and social environment within which they are produced and re-produced, suggesting that dogmatic and static adherence is often an exception" (Cavatorta and Merone 2015). When one adopts this view of ideological development, post-Islamism is no longer about failure but reforms because the "moderation" of Ennahda has been achieved through the reinterpretation of religious concepts and through references of religious scholars who 
had marginalized been in the past. In addition, the justification for political participation as well as the relationships the party must have with other political actors in the system is subsumed to Islam insofar as there needs to be a religion-informed discussion to validate choices and actions. The significance of this should not be underestimated because it is not simply an instrumental reading designed to confirm the pragmatic choices the party made, but it is a genuine process of rethinking that needs to be substantiated through religious concepts. Ideology and ideological claims—and their evolution-are at the centre of the analysis of post-Islamism and the Ennahda fits within this post-Islamist trajectory (Wolf 2017), as its own internal debates about how to advance Islamism and protect the "sacred" in a reconstructed secular environment demonstrate (McCarthy 2014). When this aspect is taken into account, one can argue that the Islamist project has not failed, but it has simply evolved while maintaining the centrality of Islam. For instance, the renunciation to references to sharia in the constitution is not a failure of the Islamist project, but an evolution (Warren 2012) of it insofar as other aspects of the Islamist project have become more important because of the changes that have taken place in society and institutionally. Thus, Ghannouchi can claim that party today is has accomplished a much greater "Islamist" objective than simply placing sharia in the constitution as a reference for legislation and policy-making; Tunisian Islamism has succeeded in creating the conditions-democracyfor justice and liberty to triumph. Both are seen as the fundamental pillars of how an Islamic society should be governed. There is certainly a degree of "clutching at straws" on the part of Ghannouchi and the party's leadership in pushing the notions of liberty and justice as the genuine objectives of Islam to justify their pragmatic political choices. However, this should not be dismissed as purely instrumental or self-serving, but also as the outcome of "a complex process of ideological revision and soul-searching that uses religious categories and intellectuals to legitimise the evolutionary process. In turn, as mentioned above, such a process influences the way in which daily politicking is practiced in a sort of feedback loop" (Cavatorta and Merone 2015). As Marks (2014) also argues, the connection between liberal values and meaningful piety flow almost naturally in Ennahda's discourse and this can point to the rejuvenation of the Islamist project rather than its failure. More recently Meddeb (2019, p. 1) has argued that "moving away from an Islamist ideology meant rethinking the party's relationship with Tunisia's religious sphere", but rethinking does not necessarily equate with failure. If anything, the "rethink" might lead the party back to its roots, particularly if the electoral losses are perceived as being the product of having moved too far away from core identity issues linked to religion.

It is at this juncture that the notion of post-Islamism as understood by Bayat in his work following the Arab uprisings can retain some analytical usefulness. In short, post-Islamism becomes a valuable category because it confirms that the process of adaptation of the party has indeed led to the fusion of religion and politics whereby political categories prevail over religious ones because the party has modernized when it accepted democratic procedures and individual freedoms as cornerstones of the political system. Given the nature of the process of adaptation and the Tunisian ideological references the party employed, this post-Islamist vision is not only a western analytical imposition, but a local reflection. And yet, the process of adaptation and therefore the label post-Islamist sits uneasily in some respects because the difficulty the party has in exiting political Islam (Meddeb 2019) are significant and some issues are left unresolved. Two stand out. The first one has to do with the way in which the party justifies policy changes and choices to its members. Here, the primacy of religious categories again takes centre-stage, as Salem Ben (2020) underlines for instance when looking at the party's adaptation to the market economy. The second has to do with the party's relations with other actors. The rivalry between "mainstream" Islamists and Salafis is a useful testing ground for this notion of post-Islamism because it allows us to see how Ennahda still sees Islam as central to its organizing ideological principles to face competition from within the broader Islamist camp. 


\section{Ennahda and Salafism}

Bayat's post-Islamism can be "tested" by looking at the way in which the Tunisian transition evolved initially around the ideological and political dialectic between Ennahda and the multi-faceted Salafi movement. Crucial to the success of the Tunisian process of democratization is in fact a paradox at the heart of it. The Tunisian political consensus, with Ennahda as a protagonist, on the construction of democratic pluralistic and liberal political system has been built around the repression of Salafism and the return of "deep state". Although the return of widespread and arbitrary repression (Yerkes 2018) is being carried out in the name of securitizing the transition and the country as a whole, Ennahda has used theological discussions to side with the rest of the political establishment against the Salafis rather than clearly employing the language of democracy. In some sense the elimination of jihadi Salafism in all of its complexity (Torelli et al. 2012; Marks 2013) responded to the Tunisian logic of denying full citizenship rights to those elements within society who do not buy into the notion of tunisianité, which is some sort of distinctive character Tunisians are supposed to have when it comes to respecting and tolerating social and religious pluralism. Ennahda has fully embraced the rhetoric of this notion in its effort to present itself as a Tunisian party and not an extension of a unified transnational Islamist movement (Cavatorta and Merone 2015).

The elimination of Salafism from the Tunisian scene responded to genuine security concerns. Terrorist attacks in 2015, the small insurgency in the west of the country as well as the chaos in neighbouring Libya all testify to the real menace of terrorism. There is also no doubt that jihadi Salafis were involved in violence prior to their ban, as the attack on the US Embassy in September 2012 indicates. However, this section looks at the way in which a competing, although minoritarian, national narrative of Tunisia and vision of the future - the Salafi one- - has been dealt with. The section is therefore preoccupied with the question of how the "conflict" between jihadi Salafis and Ennahda speaks to the relevance of post-Islamism, as the Ennahda's decision to support a repressive turn against Ansar a-Sharia (AST henceforth), the leading Salafi association since the revolution until its ban in the summer of 2013, needed an ideological justification. This was even more the case given the party's previous experience of its own repression and its reluctance to side with the repressive apparatus of the state.

The prominent role Salafism-in all its guises-played in the aftermath of the Tunisian revolution and subsequent process of regime change has been explored in detail elsewhere (Marks 2012; Wolf and Levefre 2012; Gartenstein-Ross et al. 2014) and while they have focused on different aspects of the phenomenon, the central preoccupation was Salafi influence on the fragile process of democratic change. One aspect however that has yet to be fully explored has to do with the complex relationship between the broader Salafi movement and the mainstream Islamist party Ennahda. There have of course been superficial accounts of this relationship, particularly in the Tunisian and French press, because Tunisian Salafism was for many a surprising public presence in a country supposedly immune from this type of religious conservatism. Broadly speaking, such analyses suggested that there was a significant degree of connivance between Salafis and Ennahda and that their intent was similar, namely the creation of an Islamic state that would revert Tunisia back to authoritarian rule through the instauration of a theocracy. These analyses rested on the assumption that Ennahda had a public rhetoric focused on democracy, civil state and tolerance while in reality it "used" Salafis to put pressure on the political system to arrive at an institutional outcome that was very different from the one they promoted in public; they wanted the creation of an Islamic state. Fear of Islamism, in all of its persuasions, was one of the dominant themes running through the examination of the relationship between the Salafis and Ennahda. The reality was and still is much more complex and this can be argued without completely discarding the idea that some within Ennahda did think that the pressure coming from Salafis could be beneficial for the party. The complexity of the relationship rests on a number of dimensions. 
First, the party was as surprised as all the other political actors by the rapid rise and appeal of jihadi Salafism. Members of the party were aware that a chunk of Tunisian youth had been involved in foreign "jihads" (Zelin 2020) and that a degree of radicalization through satellite TV and the Internet had indeed taken place under Ben Ali (Hostrup Haugbølle 2015), but the extent of the appeal and the visibility jihadi Salafists acquired after the revolution was shocking for the party. Second, Ennahda found very quickly that these young self-styled jihadi Salafis had very little time for party politics and for the institutionalization of the revolution. In fact, embracing Salafism seemed to suggest that the revolution was not over (Merone 2015) for a segment of young people, whose jihadi engagement did not necessary entail political violence, but an attitude closer to the one the Jordanian sheikh al-Maqdisi set forth of using dawa as jihad (Wagemakers 2012) to overthrow the political order. Finally, it became clear quite quickly that there was little to no ideological proximity between the two, although Ennahda contains what can be called a "Salafi" wing, much closer in any case to political Salafis (Wiktorowicz 2006) than to the jihadi ones.

Under closer examination, the relationship between Ennahda and the jihadi Salafis of AST, could be described — when AST was declared a terrorist organisation-as both paternal and paternalistic until August 2013, although it had been clear since the attack on the US embassy in 2012 that Salafism could not necessarily be engaged through dialogue. The latter term better explains how Ennahda attempted to incorporate Salafis into the discourse and practice of the transition until the summer of 2013. This was very much in evidence at the local level where Ennahda militants, who often knew personally the young people involved in Salafi activism, tried to keep channels of communication open with them and make them understand the importance of acting "responsibly" to avoid the collapse of the transition. The language employed to do so was not political, but religious. This is because Ennahda believed that the party would be the main loser if the transition failed. From the party leadership down to local party members in disenfranchised neighbourhoods where Salafis were particularly active, the key word and idea was dialogue; an attempt to discuss with and engage Salafis on the merits of creating a pluralistic political system supported by democratic mechanisms and respect for individual rights. What should also be highlighted though is that such dialogue was not based on the values of democracy and liberalism because the categories of Political Islam had not been entirely abandoned. Far from that, Salafis were engaged through the "shared" language of religion and how it applied to politics, with nahdawis arguing that religious concepts and injunctions had to be reinterpreted. Ennahda's goal was to bring the Salafis around the idea that a different conceptualization of Islamic state was necessary, reminding the Salafi youth that a move away from a traditionally understood Islamic state was not a betrayal. In this sense Roy's post-Islamism is quite unhelpful because it suggests, as mentioned earlier, a failure of Islamism in its ultimate objective - the creation of the Islamic state-and fails to conceive of the possibility that the Islamic state and the path on how the party could get there can be reinterpreted, while remaining fully committed to the use of Islam to get there. Thus, Salafis were engaged with through religion, the "language" that Salafis themselves employ. In this way it becomes possible to see how the dynamic relationship with other actors in the system, in this case Salafis, can better clarify how analysts can employ the thesis of post-Islamism.

By the early 2000s the Ennahda leadership argued openly that the true Islamic state is one where democracy triumphs because only democracy can deliver justice and justice is the ultimate goal of Islam, hence the goal of an Islamic democracy which differs greatly from the notion of an Islamic state other Islamists might have (Santilli and Longo 2014). It is within this Islamist framework that "dialogue" with Salafis occurred. This is not to suggest that there were no instrumental reasons to enter into a dialogue with jihadi Salafis. In fact, there were at least three. First it was perceived as necessary to shore up the electoral fortunes of the party. The 2011 legislative elections were an unknown for the leadership and making sure that at least some Salafis would turn up and vote for the party 
was important to show the strength of the Islamist constituency. Second was the concern that the rise of jihadi Salafism with symbols of war and its excitable audience would trigger a backlash against all Islamists, including Ennahda. After all, Ben Ali's security forces had been trained for decades to see all Islamists as the enemies of the country and not only of the regime. Third was the preoccupation that the process of Salafist radicalization would divide Tunisian society further apart than it already was, resulting in backlash against Ennahda as had occurred in the 1990s (Alexander 2010).

These self-serving reasons for dialogue do not invalidate though the previous point about the manner of the engagement, which relied heavily on Islamist categories and scholars in order to be legitimate. This can be seen in part in the paternalism involved in the dialogue with Salafis, insofar as the argument was often made that they were young and excitable just like today's Ennahda leaders were in their youth, and that they should be encouraged to moderate as they had done while still following the teachings and scholarships of leading Islamist thinkers, although not necessarily the ones that had informed the views of the movement in the 1970s. In light of this emphasis on dialogue and on the similarity that nahdawis of an older generation saw between them in the past and Salafis today it is no surprise that, for almost two years, repressing AST through the apparatus of the state did not feature in Ennahda's strategy. The logic behind the choice of dialogue rested on the assumption that ideologies cannot be suppressed through police tactics, that individuals are responsible for acts of violence and that therefore what individuals do should not be ascribed to an entire movement. In short, freedom of expression and personal responsibility were the framework through which Salafis were allowed to operate. The issue was not whether Salafis could be brought around the acceptance of democracy and liberal rights but was whether they would be allowed to say they were against them and still be part of the broader pluralistic system being constructed. In this sense the similar approach to Salafis of Ennahda and secular figures like Marzouki, who also favoured dialogue, strengthens the idea of Bayat's post-Islamism because it points to the shared nature of the way political engagement should occur insofar as it rejects exclusivity and self-righteousness in favour of critical thinking and inclusion.

While the decision to eventually ban AST and declare it a terrorist organisation was motivated by the increasing acts of violence members of AST carried out, it is still quite paradoxical that political parties and social movements that had gone through the harsh repressive measures of the Ben Ali regime resorted to a rather similar strategy to deal with the challenge of AST as a whole. Ennahda quite abruptly moved away from "dialogue" with Salafis to embrace a policy of eradication in mid-2013, negating in practice the lessons they had learned when being confronted themselves with repression, namely that ideas cannot be eliminated. There are three sets of potential reasons that are provided for this change.

First is the self-interest of Ennahda in remaining in power and therefore in control of the transition to guide it to its most beneficial conclusion for the party. Ennahda, the leading party in a coalition government since late 2011 until early 2014, had come under severe criticism from the opposition in the Assembly and large sectors of civil society for its ineffectiveness in solving the problems the country faced. Not only was Ennahda accused of attempting to Islamise society, but it was also deemed responsible for the deteriorating socio-economic situation. Once Salafis became very active on the public scene, the security situation also deteriorated, and the ruling coalition faced significant pressure to stamp down on the "insecurity" and instability Salafis were deemed to have created. Once it became apparent to Ennahda that large sectors of Tunisian society were increasingly keen on repressive measures against Salafis, the party gave in. The violent incidents Salafis were involved in became too numerous to ignore over time and Ennahda acted to placate the opposition.

The second reason for Ennahda's actions against Salafis had to do with the increasing belief within the nahdaoui leadership that AST would not be able to become institutionalised and that action should be taken against it before it became a powerful competitor. In this explanation, Ennahda's focus is therefore not so much on its survival as the leading party in 
the ruling coalition, but on survival itself as the leading actor in the Islamist camp. Not only was AST increasingly critical of Ennahda, it also affected the support for the party in key disenfranchised and working-class constituencies where revolutionary fervour still existed. In addition, it did not allow the party to expand its reach to the youth of these areas because the ones who were politicized favoured the harsher and more revolutionary rhetoric AST provided. Initially, the idea of dialogue stemmed in part from the assumption that some Salafis at least would turn out at the polls and support Ennahda against its nationalist secular rivals, but the reality was very different. AST did not encourage its members to vote and the members themselves were not thrilled with the prospect of turning out to vote for a party that did not even want to mention sharia in the new Constitution. Thus, AST was a competitor to be eliminated and circumstances were ripe in the summer of 2013 for banning it, providing the opportunity to consolidate the party's primacy within the Islamist camp.

The third explanation for Ennahda's u-turn on AST has to do with pressures coming from the security forces of the Minister of Interior and nationalist/secular parties as well as from civil society and foreign actors, particularly Western ones. The powerful security apparatus had retreated to the background in the aftermath of the revolution, as political parties and ordinary citizens began to vent their anger at the machinery of the state for prolonging Ben Ali's regime. Within the ministry it was decided that keeping a low profile would be the best strategy while political developments were on-going. Ennahda's victory in the elections and the appointment of Ali Larayedh, a Nahda leader who had served years in jail for his political activism, was not well accepted in security circles. The fear of widespread prosecutions as well as the frustration for accusations of abuse against all police officers created a rather poisonous environment and reforming security structures became extremely difficult (Kartas 2014; Santini and Cimini 2019). Ultimately issues of transnational justice were left aside and the rise of Salafism, with its violent outbursts, made people increasingly keen to accept a "return of the state" on the public scene to guarantee security. This popular sentiment empowered the security apparatus again and its return on the scene with the backing of the new nationalist party Nida Tounes that pressured Ennahda into compliance. In the context of this explanation, therefore, Ennahda supported the decision to ban AST in order to avoid being either branded as favouring terrorism or, worse, being dismissed from power outright through an Egypt-style scenario. All the three explanations are not mutually exclusive and a combination of the three is what emerges as the most plausible, particularly if one looks at the timing of the announcement of the ban, which came a month after the Egyptian military coup. There is no doubt that the coup provided Tunisian actors with different lessons, empowering some- the security services and the anti Islamist camp-and cornering others-Ennahda and Marzouki. The decision to ban AST is a turning point in the way in which the Tunisian state reaffirmed the primacy of security and stability over concerns for human rights and individual freedoms and its consequences are still felt in the current period of democratic consolidation.

This set of explanations has significant consequences for the post-Islamism thesis because it points to a fundamental ideological disconnect between Salafis and Ennahda, which took the form of sharp religious disagreements. Post-Islamism in this respect is useful for two reasons. First, it allows scholars and policy-makers to have a clearer sense of what is occurring within the broad Islamist "church". While the religious symbolism and references might be similar for all Islamist actors, the way in which they are understood and interpreted matters enormously, creating divisions and even conflicts among movements that are theoretically descending form similar beliefs and are committed to the same endgoals. This convergence patently does not exist, and this is precisely one of the points of post-Islamism, namely that a large sector of Islamism-in this case represented by Ennahda-now employs religious categories to connect to universal values and norms when it comes to engaging in institutional politics. At the same time, the notion of postIslamism has to be employed with greater care because it might apply very differently according to context and even according to specific circumstances, as Lauzière (2005) had 
already suggested. More recently Imad (2019) spoke of the fluid definition of the concept. Second, post-Islamism can be useful if conceived of as a trajectory for some movements and not for others. The journey of Ennahda and the efforts the party made to set jihadi Salafis on the same course suggests that one can remain an Islamist despite having come to terms with the complexity of plural societies. In this respect it is not surprising that Salafis accused Ennahda of treason of the Islamist cause and of having sold out the Islamic state for a few ministerial posts, but these accusations confirm that intra-Islamist ideological disputes remain based on the interpretation of religious scholarship for political purposes.

\section{Conclusions}

The institutional success of the Tunisian transition has benefited from the post-Islamist turn of Ennahda, but one has to be mindful that the concept describes a trajectory that can suffer from deviations. If the notion of post-Islamism is employed as an analytical category to indicate the connection between religious principles, political engagement and universal notions of democracy Ennahda fits the criteria, but if it is used to argue for the supremacy of politics over religion, more caution is needed. This is illustrated not only in the party's own internal debates, where religion occupies a prominent position, but also in relation to the relationship it has had with other actors in the broad Islamist camp, namely Salafis.

While the vast majority of Tunisians did not share the vision of society Salafis offered and were in fact frightened by it because it seemed to contradict what many Tunisians had come to understand their national narrative was, it should be highlighted that the means employed to "eliminate" this vision hark back to the way in which Ben Ali also dealt with challenges to the national narrative of tunisianité. Within this context, there is a paradox. Parties and leaders who had suffered from repression for their political beliefs promoted the same policies - based on the same anti-terror legislation-the previous regime used. Among these actors is Ennahda, which had attempted to construct dialogue with Salafis and failed to make any inroads in convincing them to support the construction of a democratic system with the argument that this represented in fact a victory for Islam. Islamism then did not fail, but simply evolved. The rivalry between Ennhada and the Salafis is a demonstration that Islam is still a central preoccupation for political actors whose ideological diverging paths remain nevertheless connected by the principle that religion should not be disconnected from politics.

Author Contributions: Both authors contributed equally to all sections of the article. Both authors have read and agreed to the published version of the manuscript.

Funding: This research received no external funding.

Informed Consent Statement: Not applicable.

Data Availability Statement: Not applicable.

Conflicts of Interest: The authors declare no conflict of interest.

\section{References}

Al-Anani, Khalil. 2012. Islamist Parties in the post-Arab Spring. Mediterranean Politics 17: 466-72. [CrossRef]

Al-Anani, Khalil. 2014. Book Review. Post-Islamism: The changing faces of Political Islam. Sociology of Islam 2: 347-65. [CrossRef]

Alexander, Christopher. 2010. Tunisia: Stability and Reform in the Modern Maghreb. London: Routledge.

Allani, Alaya. 2009. The Islamists in Tunisia between confrontation and participation: 1980-2008. Journal of North African Studies 14: 257-72. [CrossRef]

Bayat, Asef. 1996. The coming of a post-Islamist society. Middle East Critique 5: 43-52. [CrossRef]

Bayat, Asef. 2007. Making Islam Democratic: Social Movements and the Post-Islamist Turn. Stanford: Stanford University Press.

Bayat, Asef. 2010. Life as Politics: How Ordinary People Change the Middle East. Stanford: Stanford University Press.

Bayat, Asef. 2013. Post-Islamism: The Changing Faces of Political Islam. Oxford: Oxford University Press.

Ben, Salem. 2020. "God loves the rich." The Economic Policy of Ennahda: Liberalism in the Service of Social Solidarity. Politics E Religion 13: 695-718.

Browers, Michaelle. 2014. Rethinking Post-Islamism and the study of changes in Islamist ideology. Project of Middle East Political Science, Briefings 24: 16-19. 
Brown, Nathan. 2012. Why Victory Is Not an Option. Islamist Movements in Arab Politics. Ithaca: Cornell University Press.

Buehler, Matt. 2018. Why Alliances Fail: Islamist and Leftist Coalitions in North Africa. Syracuse: Syracuse University Press.

Bunzel, Cole. 2015. From paper state to Caliphate: The ideology of the Islamic State. Center for Middle East Policy at Brookings 19: 1-45.

Cavatorta, Francesco, and Fabio Merone. 2013. Moderation through exclusion? The journey of the Tunisian Ennahda from fundamentalist to conservative party. Democratization 20: 857-75. [CrossRef]

Cavatorta, Francesco, and Fabio Merone. 2015. Post-Islamism, ideological evolution and 'la tunisianité' of the Tunisian Islamist party Ennahda. Journal of Political Ideologies 20: 27-42. [CrossRef]

Cavatorta, Francesco, and Lise Storm. 2018. Political Parties in the Arab World. Edinburgh: Edinburgh University Press.

Clark, Janine. 2010. Threats, Structures, and Resources: Cross-Ideological Coalition Building in Jordan. Comparative Politics 43: 101-20. [CrossRef]

El-Ghobashy, Mona. 2005. The Metamorphosis of the Egyptian Muslim Brothers. International Journal of Middle East Studies 37: $373-95$. [CrossRef]

Gartenstein-Ross, Daveed, Bridget Moreng, and Kathleen Soucy. 2014. Raising the Stakes: Ansar al-Shari'a in Tunisia's Shift to Jihad. ICCT Research Paper. The Hague: ICCT, February.

Gerges, Fawaz. 2013. The Islamist movement: From Islamic state to Civil Islam? Political Science Quarterly 128: 389-426. [CrossRef]

Ghannouchi, Rached. 2016. From Political Islam to Muslim democracy. Foreign Affairs 95: 63-86.

Haenni, Patrick. 2005. L'Islam de Marché: L'autre Révolution Conservatrice. Paris: Seuil.

Hamid, Shadi. 2011. The rise of the Islamists. Foreign Affairs 90: 40-47.

Haugbølle, Rikke, and Francesco Cavatorta. 2012. Beyond Ghannouchi: Islamism and social change in Tunisia. Middle East Report 262: 20-25.

Hostrup Haugbølle, Rikke. 2015. New expressions of Islam in Tunisia: An ethnographic approach. Journal of North African Studies 20: 319-35. [CrossRef]

Imad, Abdul Ghani. 2019. Post-Islamism: Ideological Delusions and Sociological Realities. Contemporary Arab Affairs 12: 3-20. [CrossRef]

Kartas, Moncef. 2014. Foreign Aid and Security Sector Reform in Tunisia: Resistance and Autonomy of the Security Forces. Mediterranean Politics 19: 373-91. [CrossRef]

Kraetzschmar, Hendrik, and Francesco Cavatorta. 2010. Bullets over ballots: Islamist groups, the State and election violence in Egypt and Morocco. Democratization 17: 326-49. [CrossRef]

Lauzière, Henri. 2005. Post-Islamism and the religious discourse of Abdessalam Yassin. International Journal of Middle Eastern Studies 37: 241-61. [CrossRef]

Lesch, Ann. 2014. Troubled political transitions: Tunisia, Egypt and Libya. Middle East Policy 21: 62-74. [CrossRef]

Marks, Monica. 2012. Who are Tunisia's Salafis?' Foreign Policy, The Middle East Channel. September 28. Available online: http:/ / mideast.foreignpolicy.com/posts/2012/09/28/who_are_tunisia_s_salafis?wp_login_redirect=0 (accessed on 30 September 2012).

Marks, Monica. 2013. Youth Politics and Tunisian Salafism: Understanding the Jihadi Current. Mediterranean Politics 18: 104-11. [CrossRef]

Marks, Monica. 2014. Convince, Coerce of Compromise? Ennahda's Approach to Tunisia's Constitution. In Analysis Paper. Washington, DC: Brookings Institution. Available online: http:/ /www.brookings.edu/ \{\}/media/research/files/papers/2014/02/10\%2 0ennahda\%20tunisia\%20constitution\%20marks/ennahda\%20approach\%20tunisia\%20constitution\%20english.pdf (accessed on 15 March 2014).

Marks, Monica. 2018. Purists and pluralists: Cross-ideological colaition building in Tunisia's democratic transition. In Democratic Transntion in the Muslim World. Edited by Alfred Stepan. New York: Columbia University Press, pp. 91-120.

Masoud, Tarek. 2014. Counting Islam: Religion, Class and Elections in Egypt. Cambridge: Cambridge University Press.

McCarthy, Rory. 2014. Re-thinking secularism in post- independence Tunisia. Journal of North African Studies 19: 733-50. [CrossRef]

McCarthy, Rory. 2015. Protecting the Sacred: Tunisia's Islamist Movement Ennahda and the Challenge of Free Speech. British Journal of Middle Eastern Studies 42: 447-64. [CrossRef]

McCarthy, Rory. 2018. When Islamists Lose: The politicization of Tunisia's Ennahda Movement. Middle East Journal 72: 365-84. [CrossRef]

Meddeb, Hamza. 2019. Ennahda's Uneasy Exit from Political Islam. Beirut: Carnegie Middle East Center, September 1-29. Available online: https:/ / carnegieendowment.org/files/WP_Meddeb_Ennahda1.pdf (accessed on 19 September 2020).

Merone, Fabio. 2015. Enduring class struggle in Tunisia: The fight for identity beyond Political Islam. British Journal of Middle Eastern Studies 42: 74-87. [CrossRef]

Netterstrøm, Kasper. 2015. After the Arab Spring: The Islamists' compromise in Tunisia. Journal of Democracy 26: 110-24. [CrossRef]

Roy, Olivier. 1992. L'Echec de l'Islam Politique. Paris: Seuil.

Roy, Olivier. 2012. The transformation of the Arab world. Journal of Democracy 23: 5-18. [CrossRef]

Santilli, Anthony, and Pietro Longo. 2014. Tunisia: Modelli di stato islamico a confront. Storia del Pensiero Politico 3: $399-422$.

Santini, Ruth, and Giulia Cimini. 2019. The politics of security reform in post-2011 Tunisia: Assessing the role of exogenous shocks, domestic policy entrepreneurs and external actors. Middle Eastern Studies 55: 225-41. [CrossRef]

Schwedler, Jillian. 2011. Can Islamists become moderates? World Politics 63: 347-76. [CrossRef] 
Schwedler, Jillian. 2013. Islamists in power? Inclusion, moderation and the Arab uprisings. Middle East Development Journal 5: 1-18. [CrossRef]

Tamimi, Azzam. 2001. Rachid Ghannouchi: A democrat within Islam. Oxford: Oxford University Press.

Teti, Andrea, Pamela Abbott, and Francesco Cavatorta. 2019. Do Arabs really want democracy? Evidence from four countries. Democratization 26: 645-65. [CrossRef]

Torelli, Stefano, Fabio Merone, and Francesco Cavatorta. 2012. Salafism in Tunisia: Challenges and opportunities for democratization. Middle East Policy 19: 140-54. [CrossRef]

Wagemakers, Joas. 2012. A Quietist Jihadi: The Ideology and Influence of Abu Muhammad Al-Maqdisi. Cambnridge: Cambridge University Press.

Warren, David. 2012. The Entrance of the Maqasid al-Shariah into Contemporary Muslim Political and Jurisprudential Discourse: The Case of Rashid al-Ghannushi and Ennahda. Journal of Islamic State Practices in International Law 8: 82-91.

Wegner, Eva, and Francesco Cavatorta. 2019. Revisiting the Islamist-Secular divide: Parties and Voters in the Arab World. International Political Science Review 40: 558-75. [CrossRef]

Wiktorowicz, Quintan. 2006. Anatomy of the Salafi Movement. Studies in Conflict \& Terrorism 29: 207-40.

Willis, Michael. 2004. Morocco's Islamists and the legislative elections of 2002: The strange case of the party that did not want to win. Mediterranean Politics 9: 53-81. [CrossRef]

Wolf, Anne. 2017. Political Islam in Tunisia: A History of Ennahda. London: Hurst \& Co.

Wolf, Anne, and Raphael Levefre. 2012. The Demon or the Demonized? Deconstructing 'Salafism' in Tunisia. Open Democracy, June 5. Available online: https://www.opendemocracy.net/en/demon-or-demonized-deconstructing-salafism-in-tunisia/ (accessed on 15 February 2013).

Yerkes, Sarah. 2018. The Quiet Threat to Human Rights in Tunisia.' Tunisia Monitor, Carnegie Endowment for International Peace, Op-ed. Available online: http://carnegieendowment.org/2018/08/07/quiet-threat-to-human-rights-in-tunisia-pub-77004 (accessed on 10 October 2018).

Yilmaz, Ihsan. 2011. Beyond post-Islamism: Transformation of Turkish Islamism towards 'civil Islam' and its potential influence in the Muslim World. European Journal of Economics and Political Studies 4: 245-80.

Zelin, Aaron. 2020. Your Sons Are at Your Service. New York: Columbia University Press. 